\title{
The cytoprotective and the dark side of Nrf2
}

\author{
R. Marchan · H. M. Bolt
}

Published online: 14 November 2013

(C) Springer-Verlag Berlin Heidelberg 2013

In 1988, Paul Talalay and colleagues described a protein with highly reactive cysteine residues that protects against chemical carcinogenesis (Talalay et al. 1988) This led to the discovery of an elaborate network of highly inducible, cytoprotective proteins that are controlled by the Keap1-Nrf2 pathway (Itoh et al. 1999; Dinkova-Kostova et al. 2002; Kobayashi et al. 2004; Wakabayashi et al. 2004; Motohashi and Yamamoto 2004; Zhang and Hannink 2003; Balogun et al. 2003; McMahon et al. 2003; Zhang et al. 2004; Kwak et al. 2003). In the following decades, the Keap1-Nrf2-signaling axis became one of the most studied topics in toxicology. Therefore, it comes as no surprise that two of the most discussed invited reviews published in the Archives of Toxicology highlight the importance of this pathway (Baird and Dinkova-Kostova 2011; Slocum and Kensler 2011) (Table 1). Nrf2 is bound by Keap1 via two binding sites, the so-called hinge and latch domains. Following binding, Nrf2 is ubiquitinated and degraded by the proteasome, which controls Nrf2 basal levels. Chemicals or cell stress may disrupt the interaction between Nrf2 and Keap1 leading to inefficient ubiquitination of Nrf2. Instead, Nrf2 accumulates and translocates to the nucleus

R. Marchan · H. M. Bolt $(\bowtie)$

Leibniz Institut für Arbeitsforschung an der TU Dortmund, Leibniz Research Centre for Working Environment and Human Factors (IfADo), Ardeystrasse 67, 44139 Dortmund, Germany e-mail: bolt@ifado.de where it induces transcription of a number of cytoprotective genes.

In their comprehensive review, Baird and DinkovaKostova (2011) present different models of regulation, such as the 'sequester and release model' for Keap1$\mathrm{Nrf} 2$, the role of cullin 3 during dissociation, the hinge and latch model, sensing of inducers by Nrf2 and the role of phosphorylation. Moreover, a comprehensive overview of cytoprotective Nrf2 target genes and the chemistry of inducers are provided. In a complementary review, Slocum and Kensler (2011) focus on genetic mouse models of the Keap 1-Nrf2 pathway and its role in carcinogenesis of the colon, bladder, lung, stomach, skin, liver and breast. Upregulation of Nrf2 signaling provides tumor cells with a survival advantage in adverse environments (Slocum and Kensler 2011). Moreover, Nrf2 also upregulates the expression of the multidrug-resistant protein-3 (MRP3), which exports a variety of cytostatic drugs, including chlorambucil, cisplatin, doxorubicin and etoposide.

Further influential articles published in the Archives of Toxicology in recent years focus on nanotoxicity (Kim et al. 2012; Landsiedel et al. 2012; Nunes et al. 2012; Trpkovic et al. 2012; Gebel 2012; Oesch and Landsiedel 2012), the use of stem cells in toxicology (Wobus and Löser 2011; Krug et al. 2013; Seiler et al. 2011), carcinogenesis (Bernstein et al. 2011; Golka et al. 2011; Burns and Korach 2012; Pavanello and Lotti 2012; Brambilla et al. 2011), metal toxicology (Chasapis et al. 2012), neurotoxicity (Soderlund 2012; Carvalho et al. 2012; Mariussen 2012), in silico and in vitro methods (Karp and Caspi 2011; Godoy et al. 2013; Mehling et al. 2012; Geenen et al. 2012) and oxidative stress (Matés et al. 2012). The editors hope that this choice meets the current needs of our readers, and encourage them to suggest further 
Table 1 Overview of the most discussed review articles

\begin{tabular}{|c|c|c|}
\hline Key message & $\begin{array}{l}\text { No. of } \\
\text { citations }\end{array}$ & Reference \\
\hline $\begin{array}{l}\text { Chemicals react with cysteine residues of Keap1. This leads to stabilization and nuclear } \\
\text { translocation of the transcription factor, Nrf2. Finally, cytoprotective Nrf2-dependent genes } \\
\text { become expressed }\end{array}$ & 89 & Baird and Dinkova-Kostova (2011) \\
\hline $\begin{array}{l}\text { An expert panel estimated the time necessary to achieve full replacement of animal testing. } \\
\text { Time frames of 7-9 and 5-7 years are discussed for skin sensitization and toxicokinetics, } \\
\text { respectively. However, a timeline cannot be estimated for repeated-dose toxicity, carcino- } \\
\text { genicity and reproductive toxicity }\end{array}$ & 63 & Adler et al. (2011) \\
\hline $\begin{array}{l}\text { Inorganic selenium interacts with endogenous - } \mathrm{SH} \text { groups, thus explaining some of its } \\
\text { toxicological effects. The potential use of organoselenium as a therapeutic has not yet been } \\
\text { sufficiently explored }\end{array}$ & 52 & Nogueira and Rocha (2011) \\
\hline $\begin{array}{l}\text { Many studies with Nrf-2 knockout mice demonstrate its key role in carcinogenesis of the } \\
\text { colon, bladder, lung and stomach, and its relevance to inflammation control }\end{array}$ & 39 & Slocum and Kensler (2011) \\
\hline $\begin{array}{l}\text { Gas or liquid chromatography coupled to mass spectrometry allows the quantification of } \\
\text { thousands of metabolites. However, despite intensive research in the field of metabolomics, } \\
\text { no metabolites have been successfully introduced into routine clinical practice. This review } \\
\text { critically discusses the state of the art in the field of inborn errors of metabolism, cardiovas- } \\
\text { cular disease and cancer }\end{array}$ & 38 & Mamas et al. (2011) \\
\hline $\begin{array}{l}\text { The micronucleus assay is used to detect aneugens and clastogens. The 'cytokinesis-block } \\
\text { micronucleus assay' evaluates nucleoplasmic bridges, cell division inhibition, nuclear buds, } \\
\text { apoptosis and necrosis. This review gives an overview of current protocols, high-throughput } \\
\text { methods and the biological background of the micronucleus assay }\end{array}$ & 36 & Kirsch-Volders et al. (2011) \\
\hline $\begin{array}{l}\text { This review provides an overview of standardized methods to analyze the antioxidative capac- } \\
\text { ity of chemicals, with particular focus on food constituents }\end{array}$ & 35 & Gülçin (2012) \\
\hline $\begin{array}{l}\text { Cell signaling activated by nanoparticles includes P38, JNK, NF kappa B and Nrf2 and is } \\
\text { associated with the capacity to induce cytotoxicity }\end{array}$ & 30 & Marano et al. (2011) \\
\hline $\begin{array}{l}\text { The surface modifications of nanocrystal quantum dots, and not their core metalloid complex, } \\
\text { are responsible for most of the observed toxic effects }\end{array}$ & 27 & Hoshino et al. (2011) \\
\hline $\begin{array}{l}\text { This review discusses the possibilities and limitations of in vitro testing for the evaluation of } \\
\text { human health risks }\end{array}$ & 25 & Clift et al. (2011) \\
\hline
\end{tabular}

The number of citations that are current as of October 14, 2013

cutting-edge topics, and of course the authors who will contribute to future comprehensive and insightful review articles.

\section{References}

Adler S, Basketter D, Creton S, Pelkonen O, van Benthem J, Zuang V, Andersen KE, Angers-Loustau A, Aptula A, Bal-Price A, Benfenati E, Bernauer U, Bessems J, Bois FY, Boobis A, Brandon E, Bremer S, Broschard T, Casati S, Coecke S, Corvi R, Cronin M, Daston G, Dekant W, Felter S, Grignard E, Gundert-Remy U, Heinonen T, Kimber I, Kleinjans J, Komulainen H, Kreiling R, Kreysa J, Leite SB, Loizou G, Maxwell G, Mazzatorta P, Munn S, Pfuhler S, Phrakonkham P, Piersma A, Poth A, Prieto P, Repetto G, Rogiers V, Schoeters G, Schwarz M, Serafimova R, Tähti H, Testai E, van Delft J, van Loveren H, Vinken M, Worth A, Zaldivar JM (2011) Alternative (non-animal) methods for cosmetics testing: current status and future prospects-2010. Arch Toxicol 85:367-485. doi:10.1007/s00204-011-0693-2.Review

Baird L, Dinkova-Kostova AT (2011) The cytoprotective role of the Keap1-Nrf2 pathway. Arch Toxicol 85:241-272. doi:10.1007/ s00204-011-0674-5.Review

Balogun E, Hoque M, Gong P, Killeen E, Green CJ, Foresti R, Alam J, Motterlini R (2003) Curcurnin activates the haem oxygenase-1 gene via regulation of $\mathrm{Nrf} 2$ and the antioxidant-responsive element. Biochem J 371:887-895. doi:10.1042/BJ20021619

Bernstein C, Holubec H, Bhattacharyya AK, Nguyen H, Payne CM, Zaitlin B, Bernstein H (2011) Carcinogenicity of deoxycholate, a secondary bile acid. Arch Toxicol 85:863-871. doi:10.1007/ s00204-011-0648-7

Brambilla G, Mattioli F, Robbiano L, Martelli A (2011) Genotoxicity and carcinogenicity studies of antihistamines. Arch Toxicol 85:1173-1187. doi:10.1007/s00204-011-0659-4

Burns KA, Korach KS (2012) Estrogen receptors and human disease: an update. Arch Toxicol 86:1491-1504. doi:10.1007/ s00204-012-0868-5

Carvalho M, Carmo H, Costa VM, Capela JP, Pontes H, Remião F, Carvalho F, de Bastos LM (2012) Toxicity of amphetamines: an update. Arch Toxicol 86:1167-1231. doi:10.1007/s00204-0120815-5.Review

Chasapis CT, Loutsidou AC, Spiliopoulou CA, Stefanidou ME (2012) Zinc and human health: an update. Arch Toxicol 86:521-534. doi:10.1007/s00204-011-0775-1

Clift MJ, Gehr P, Rothen-Rutishauser B (2011) Nanotoxicology: a perspective and discussion of whether or not in vitro testing is a valid alternative. Arch Toxicol 85:723-731. doi:10.1007/ s00204-010-0560-6

Dinkova-Kostova AT, Holtzclaw WD, Cole RN, Itoh K, Wakabayashi N, Katoh Y, Yamamoto M, Talalay P (2002) Direct evidence that sulfhydryl groups of Keap1 are the sensors regulating induction 
of phase 2 enzymes that protect against carcinogens and oxidants. Proc Natl Acad Sci USA 99:11908-11913. doi:10.1073/p nas. 172398899

Gebel $T$ (2012) Small difference in carcinogenic potency between GBP nanomaterials and GBP micromaterials. Arch Arch Toxicol 86(8):1251-1271. doi:10.1007/ s00204-012-0857-8.Epub2012May9

Geenen S, Taylor PN, Snoep JL, Wilson ID, Kenna JG, Westerhoff HV (2012) Systems biology tools for toxicology. Arch Toxicol 86:995-1007. doi:10.1007/s00204-012-0835-1.Review

Godoy P, Hewitt NJ, Albrecht U, Andersen ME, Ansari N, Bhattacharya $\mathrm{S}$, Bode JG, Bolleyn J, Borner $\mathrm{C}$, Böttger J, Braeuning A, Budinsky RA, Burkhardt B, Cameron NR, Camussi G, Cho CS, Choi YJ, Rowlands JC, Dahmen U, Damm G, Dirsch O, Donato MT, Dong J, Dooley S, Drasdo D, Eakins R, Ferreira KS, Fonsato V, Fraczek J, Gebhardt R, Gibson A, Glanemann M, Goldring CE, Gómez-Lechón MJ, Groothuis GM, Gustavsson L, Guyot C, Hallifax D, Hammad S, Hayward A, Häussinger D, Hellerbrand C, Hewitt P, Hoehme S, Holzhütter HG, Houston JB, Hrach J, Ito K, Jaeschke H, Keitel V, Kelm JM, Park BK, Kordes C, KullakUblick GA, LeCluyse EL, Lu P, Luebke-Wheeler J, Lutz A, Maltman DJ, Matz-Soja M, McMullen P, Merfort I, Messner S, Meyer C, Mwinyi J, Naisbitt DJ, Nussler AK, Olinga P, Pampaloni F, Pi J, Pluta L, Przyborski SA, Ramachandran A, Rogiers V, Rowe C, Schelcher C, Schmich K, Schwarz M, Singh B, Stelzer EH, Stieger B, Stöber R, Sugiyama Y, Tetta C, Thasler WE, Vanhaecke T, Vinken M, Weiss TS, Widera A, Woods CG, Xu JJ, Yarborough KM, Hengstler JG (2013) Recent advances in 2D and 3D in vitro systems using primary hepatocytes, alternative hepatocyte sources and non-parenchymal liver cells and their use in investigating mechanisms of hepatotoxicity, cell signaling and ADME. Arch Toxicol 87(8):1315-1530. doi:10.1007/s00204-013-1078-5

Golka K, Selinski S, Lehmann ML, Blaszkewicz M, Marchan R, Ickstadt K, Schwender H, Bolt HM, Hengstler JG (2011) Genetic variants in urinary bladder cancer: collective power of the "wimp SNPs". Arch Toxicol 85:539-554. doi:10.1007/s00204-0110676-3.Review

Gülçin I (2012) Antioxidant activity of food constituents: an overview. Arch Toxicol 86:345-391. doi:10.1007/s00204-011-0774-2

Hoshino A, Hanada S, Yamamoto K (2011) Toxicity of nanocrystal quantum dots: the relevance of surface modifications. Arch Toxicol 85:707-720. doi:10.1007/s00204-011-0695-0

Itoh K, Wakabayashi N, Katoh Y et al (1999) Keap1 represses nuclear activation of antioxidant responsive elements by Nrf2 through binding to the amino-terminal Neh2 domain. Genes Dev 13:7686. doi: $10.1101 /$ gad.13.1.76

Karp PD, Caspi R (2011) A survey of metabolic databases emphasizing the MetaCyc family. Arch Toxicol 85:1015-1033. doi:10.1007/s00204-011-0705-2

Kim JE, Shin JY, Cho MH (2012) Magnetic nanoparticles: an update of application for drug delivery and possible toxic effects. Arch Toxicol 86:685-700. doi:10.1007/s00204-011-0773-3

Kirsch-Volders M, Plas G, Elhajouji A, Lukamowicz M, Gonzalez L, Vande Loock K, Decordier I (2011) The in vitro MN assay in 2011: origin and fate, biological significance, protocols, high throughput methodologies and toxicological relevance. Arch Toxicol 85:873-899. doi:10.1007/s00204-011-0691-4.Review

Kobayashi A, Kang MI, Okawa H, Ohtsuji M, Zenke Y, Chiba T, Igarashi K, Yamamoto M (2004) Oxidative stress sensor Keap1 functions as an adaptor for Cul3-based E3 ligase to regulate for proteasomal degradation of Nrf2. Mol Cell Biol 24:7130-7139. doi: 10.1128/MCB.24.16.7130-7139

Krug AK, Kolde R, Gaspar JA, Rempel E, Balmer NV, Meganathan K, Vojnits K, Baquié M, Waldmann T, Ensenat-Waser R, Jagtap S, Evans RM, Julien S, Peterson H, Zagoura D, Kadereit S, Gerhard D, Sotiriadou I, Heke M, Natarajan K, Henry M, Winkler J,
Marchan R, Stoppini L, Bosgra S, Westerhout J, Verwei M, Vilo J, Kortenkamp A, Hescheler J, Hothorn L, Bremer S, van Thriel C, Krause KH, Hengstler JG, Rahnenführer J, Leist M, Sachinidis A (2013) Human embryonic stem cell-derived test systems for developmental neurotoxicity: a transcriptomics approach. Arch Toxicol 87(1):123-143. doi:10.1007/s00204-012-0967-3

Kwak MK, Wakabayashi N, Itoh K, Motohashi H, Yamamoto M, Kensler TW (2003) Modulation of gene expression by cancer chemopreventive dithiolethiones through the Keap1-Nrf2 pathway - Identification of novel gene clusters for cell survival. J Biol Chem 278:8135-8145. doi:10.1074/jbc.M211898200

Landsiedel R, Fabian E, Ma-Hock L, van Ravenzwaay B, Wohlleben W, Wiench K, Oesch F (2012) Toxico-/biokinetics of nanomaterials. Arch Toxicol 86:1021-1060. doi:10.1007/s00204-012-0858-7

Mamas M, Dunn WB, Neyses L, Goodacre R (2011) The role of metabolites and metabolomics in clinically applicable biomarkers of disease. Arch Toxicol 85:5-17. doi:10.1007/ s00204-010-0609-6

Marano F, Hussain S, Rodrigues-Lima F, Baeza-Squiban A, Boland S (2011) Nanoparticles: molecular targets and cell signalling. Arch Toxicol 85:733-741. doi:10.1007/s00204-010-0546-4

Mariussen E (2012) Neurotoxic effects of perfluoroalkylated compounds: mechanisms of action and environmental relevance. Arch Toxicol 86(9):1349-1367. doi:10.1007/s00204-012-0822-6

Matés JM, Segura JA, Alonso FJ, Márquez J (2012) Oxidative stress in apoptosis and cancer: an update. Arch Toxicol 86:1649-1665. doi:10.1007/s00204-012-0906-3

McMahon M, Itoh K, Yamamoto M, Hayes JD (2003) Keap1dependent proteasomal degradation of transcription factor Nrf2 contributes to the negative regulation of antioxidant response element-driven gene expression. J Biol Chem 278:21592-21600. doi:10.1074/jbc.M300931200

Mehling A, Eriksson T, Eltze T, Kolle S, Ramirez T, Teubner W, van Ravenzwaay B, Landsiedel R (2012) Non-animal test methods for predicting skin sensitization potentials. Arch Toxicol 86:1273-1295. doi:10.1007/s00204-012-0867-6.Review

Motohashi H, Yamamoto M (2004) Nrf2-Keap1 defines a physiologically important stress response mechanism. Trends Mole Med 10:549-557. doi:10.1016/j.molmed.2004.09.003

Nogueira CW, Rocha JB (2011) Toxicology and pharmacology of selenium: emphasis on synthetic organoselenium compounds. Arch Toxicol 85:1313-1359. doi:10.1007/s00204-011-0720-3

Nunes A, Al-Jamal K, Nakajima T, Hariz M, Kostarelos K (2012) Application of carbon nanotubes in neurology: clinical perspectives and toxicological risks. Arch Toxicol 86:1009-1020. doi:10.1007/s00204-012-0860-0.Review

Oesch F, Landsiedel R (2012) Genotoxicity investigations on nanomaterials. Arch Toxicol 86:985-994. doi:10.1007/s00204-0120838-y.Review

Pavanello S, Lotti M (2012) Biological monitoring of carcinogens: current status and perspectives. Arch Toxicol 86:535-541. doi:10.1007/s00204-011-0793-z.Review

Seiler A, Oelgeschläger M, Liebsch M, Pirow R, Riebeling C, Tralau T, Luch A (2011) Developmental toxicity testing in the 21st century: the sword of Damocles shattered by embryonic stem cell assays? Arch Toxicol 85:1361-1372. doi:10.1007/s00204-0110767-1.Review

Slocum SL, Kensler TW (2011) Nrf2: control of sensitivity to carcinogens. Arch Toxicol 85:273-284. doi:10.1007/s00204-011-0675-4

Soderlund DM (2012) Molecular mechanisms of pyrethroid insecticide neurotoxicity: recent advances. Arch Toxicol 86:165-181. doi:10.1007/s00204-011-0726-x

Talalay P, De Long MJ, Prochaska HJ (1988) Identification of a common chemical signal regulating the induction of enzymes that protect against chemical carcinogenesis. Proc Natl Acad Sci USA $85: 8261-8265$ 
Trpkovic A, Todorovic-Markovic B, Trajkovic V (2012) Toxicity of pristine versus functionalized fullerenes: mechanisms of cell damage and the role of oxidative stress. Arch Toxicol 86:18091827. doi:10.1007/s00204-012-0859-6

Wakabayashi N, Dinkova-Kostova AT, Holtzclaw WD, Kang MI, Kobayashi A, Yamamoto M, Kensler TW, Talalay P (2004) Protection against electrophile and oxidant stress by induction of the phase 2 response: Fate of cysteines of the Keap1 sensor modified by inducers. Proc Natl Acad Sci USA 101:2040-2045. doi:10.10 73/pnas.0307301101

Wobus AM, Löser P (2011) Present state and future perspectives of using pluripotent stem cells in toxicology research. Arch Toxicol 85:79-117. doi:10.1007/s00204-010-0641-6
Zhang DD, Hannink M (2003) Distinct cysteine residues in Keap1 are required for Keap1-dependent ubiquitination of $\mathrm{Nrf2}$ and for stabilization of Nrf2 by chemopreventive agents and oxidative stress. Mol Cell Biol 23:8137-8151. doi:10.1128/ MCB.23.22.8137- 8151.2003

Zhang DD, Lo SC, Cross JV et al (2004) Keap1 is a redox-regulated substrate adaptor protein for a Cul3-dependent ubiquitin ligase complex. Mol Cell Biol 24:10941-10953. doi:10.1128/ MCB.24.24.10941-1 0953.2004 